\title{
ЕФЕКТИВНІСТЬ ВПЛИВУ КОМПЛЕКСНО-ТРЕНІНГОВОЇ ПРОГРАМИ НА РОЗВИТОК КОМУНІКАТИВНОГО КОМПОНЕНТУ МАЙБІТНІХ ФАХІВЦІВ РЕСТОРАННОГО БIЗНЕCУ
}

УДК: 159.923.3:640.43

\section{Приймук Олеся Олександрівна}

Аспірантка кафедри психології Київського наџіонального торговельно-економічного університету, м. Київ (Украӥна)

\begin{abstract}
Анотація. У статті представлено результати порівняльного аналізу показників комунікативної сфери контрольної (КГ) і експериментальної груп (ЕГ) студентів. Доведено ефективність розвитку комунікативного компоненту у структурі професійних важливих якостей майбутніх фахівців ресторанного бізнесу (РБ). 3 'ясовано позитивний вплив комплексно тренінгової програми (КТП) на комунікативну складову студентів експериментальної групи $в$ процесі їх освітньо-професійної діяльності про, щчо свідчать: високі показники стилю й структури міжособистісної взаємодї, сформованість адекватних способів реагування особистості на конфліктну ситуацію. Визначено, щуо у представників иієї групи в домінуючих стратегіях взаємодії з іншими людьми переважають: конкуренція, співробітництво, компроміс, а також визначено істотно вищі показників організащійних $і$ комунікативних здібностей майбутніх фахівиів ресторанного бізнесу.
\end{abstract}

Ключові слова: комунікативний компонент, ефективність, комплексно тренінгова програма, професійно важливі якості.

\section{Постановка проблеми i іï зв'язок із} науковими та практичними завданнями. Суттєві зміни в соціально-економічній сфері зумовлюють необхідність інноваційного розвитку професійної підготовки фахівців. Нині професійні стандарти потребують фахівців 3 високим рівнем професійно важливих якостей (ПВЯ). Підвищення вимог до професійної і спеціальної підготовки зумовлюють потребу всебічного, глибокого дослідження системи психологічних шляхів розвитку ПВЯ, визна- чення зовнішніх і внутрішніх чинників становлення спеціалістів, що вимагає розкриття закономірностей і особливостей формування, зокрема комунікаційної сфери та урахування психологічних складових у навчальному процесі ВНЗ. Постала гостра необхідність формування високопрофесійного, компетентного спеціаліста нової генерації, який змінив би сенс і характер професійно-психологічної комунікації відповідно до вимог сучасного ринкового середовища $[2,3,4,5]$. 
Тому, враховуючи весь спектр вимог стосовно суб'єкта і об'єкта комунікації у сфері ресторанної індустрії, формування ПВЯ, вивчення і розвиток комунікативного компоненту під час освітньо-професійної діяльності майбутніх фахівців у ВНЗ є актуальним і потребує психокорекційної роботи.

Аналіз досліджень і публікацій. Аналіз науково-психологічних джерел засвідчив, що питання дослідження комунікативної складової в структурі ПВЯ фахівців ресторанного бізнесу були вивчені у працях багатьох вітчизняних науковців. Зокрема, проблемою формування навичок професійного спілкування в процесі підготовки майбутніх спеціалістів займались Л. Карумушка; О. Креденцер; О. Леонтьєв; С. Максименко; М. Савчин; Т. Щербан. Роль професійного спілкування у становленні особистості спеціаліста розглядали Є. Зеєр; І. Зорін; Є. Ільїн; Л. Карамушка; В. Корольчук; Г. Костюк; О. Креденцер; О. Куліш; А. Мазаракі; А. Маркова [1, 2, 3, 4].

Водночас, незважаючи на численні публікації щодо комунікативної сфери фахівців, які стосуються цієї проблеми у цілому, виявилося, що практично не вивчалося питання розвитку комунікативної сфери психологічними методами саме фахівців ресторанного бізнесу.

Мета. 3'ясувати ефективність впливу комплексно-тренінгової програми на розвиток комунікативного компоненту професійно важливих якостей майбутніх фахівців ресторанного бізнесу.
Виклад основного матеріалу. У статті представлено аналіз показників комунікативного компоненту ПВЯ майбутніх фахівців після впливу КТП в експериментальній групі у порівнянні з контрольними і початковими вимірами. Виходячи з мети і завдань роботи, дослідження проводилося зі студентами першого, другого, третього, четвертого і п'ятого курсів двічі на рік, розподілених на контрольну і експериментальну групи.

Аналіз ефективності апробації КТП в комунікативній сфері здійснювали за такими показниками методик, як: «Діагностика міжособистісних відносин» (Т. Лірі), «Виявлення стратегій поведінки в конфлікті» (К. Томас) i «Дослідження комунікативних і організаторських здібностей» (КОЗ) (В. Бодров).

За інтерпретаційним змістом методика діагностика міжособистісних відносин Т. Лірі в адаптованому варіанті і спрямована на вивчення особливостей стилю й структури міжособистісної взаємодії, уяви людини про себе, своє ставлення до інших.

Оцінку стилю взаємодії здійснено за інтерпритацією автора методики Т. Лірі з максимально можливою сумою балів - 16 б., яка поділена в такому діапазоні:

0 - 4 бали - низький рівень адаптованої поведінки у взаємодії;

5 - 8 балів - оптимальний рівень адаптованої поведінки у взаємодії;

9 - 12 балів - високий ступінь схильності до дезадаптованої поведінки у міжособис- 
тісній взаємодії;

13 - 16 балів - дезадаптований ступінь поведінки аж до патологічної.

За результатами першої октанти, що спрямована на визначення рівня авторитарності у міжособистісній взаємодії, з'ясовано, що у студентів контрольної групи (КГ) в процесі навчання він не зазнає суииєвих змін і знаходиться в межах 11,- 10,1 балів. Це означає, студенти КГ знаходяться в межах високого ступеня схильності до дезадаптивної поведінки у міжособистісній взаємодії і свідчить про необхідність психокорекційної роботи з ними.

Порівняльний аналіз результатів контрольної і експериментальної груп показує, що в експериментальній групі відзначено позитивні зміни показника авторитарності відповідно з 10,7 б. (початок обстеження) до 9,0 б. на 4 курсі (при $р<0,5)$ після відповідних психокорекційних заходів. При цьому у подальшому після тренінгів особистісного зростання і мотивації до підприємницької діяльності на 4 курсі та тренінга лідерського потенціалу i впливів на особистість, цей показник суттєво змінився до 7,9 - 8,0 б., що відповідає оптимальному рівню адаптивної взаємодії особистосTi.

Отже, співставлення окремих результатів контрольної і експериментальної груп студентів за рівнем авторитарності у взаємодії показує, що в експериме6нтальній групі показники суттєво поліпшилися з 10,7 б. до 8,0 б., що свідчить про позитивний вплив і ефектив- ність корекційно тренінгової програми в динаміці освітньо-професійної діяльності. Студенти експериментальної групи після цілеспрямованої корекційної роботи характеризуються як особи впевнені у собі, наполегливі, успішні у справах 3 хорошими управлінськими і організаторськими здібностями, для них характерний адаптивний рівень поведінки у взаємодії.

Інший стиль взаємодії розглядається як егоїстичний (домінантний). У контрольної групи студентів цей показник зафіксовано на рівні 8,5 - 9,2 б. тобто, в межах початку високого рівня схильності до дизадаптивної поведінки у міжособистісній взаємодії (9 - 12 балів за інтерпретаційною оцінкою) і це є показанням до психокорекційної роботи $з$ такими особами.

У осіб експериментальної групи цей показник визначено на рівні 7,4 - 6,1 балів, що у порівнянні $з$ контрольною групою він суттєво нижчий на $1,8-2,4$ бали (при $\mathrm{p}<0,05$ ). Такі відмінності свідчать про ефективність КТП у експериментальній групі студентів, що підкреслюється позитивними зрушеннями у порівнянні іï початкового рівня $(8,5$ б.) 3 динамікою показників після використання КТП з 1 по 5 курси включно (з 7,4 б. до 6,1 б. при р<0,05).

Отже, за інтерпретацією показників цієї октанти обстежувані ЕГ після застосування КТП характеризуються, як упевнені, незалежні, орієнтовані на себе і схильні до суперництва.

Третій показник, який визначає рівень 
агресивності до оточення у осіб КГ зафіксовано на рівні 10,7 - 9,1 балів, що виявляється у межах високого ступеня схильності до дизадаптивної поведінки у міжособистісній взаємодії. Порівняння показників КГ і ЕГ студентів показує, що починаючи з першого ж обстеження після застосування КТП у студентів ЕГ спостерігаються суттєві позитивні відмінності з 7,3 до 5,9 балів (при $р<0,05$ ).

Аналогічні позитивні зміни спостерігаються у динаміці обстежених ЕГ і порівнянні початкового результату 9,6 балів та зниження агресивності на 2,3 - 3,7 балів (при $р<0,05$ ).

Отже, в ЕГ студентів після застосування КТП відбуваються позитивні істотні зміни, як у порівнянні з КГ так і у співставленні результатів 3 початковими даними. Про це свідчить те, що показник ЕГ під впливом КТП вийшов із меж високого рівня схильності до дизадаптивної поведінки у міжособистісній взаємодії до меж оптимального рівня адаптивної поведінки. При цьому студенти ЕГ після проходження КТП характеризуються як наполегливі, енергійні, цілеспрямовані у досягнені мети.

Четвертий показник, який вказує на рівень недовіри (скептицизму) у осіб контрольної групи дорівнює 11,4 - 9,5 балів, що характеризує їх як замкнених, скритних, образливих.

Результати ЕГ студентів зафіксовано від початкового рівня до суттєвого поліпшення показника після застосування КТП з 8,1 до
6,1 балів (при $\mathrm{p}<0,05)$. При цьому у порівнянні з КГ студентів спостерігаються суттєво кращі показники в ЕГ в динаміці обстеження на 3,9 3,4 балів (при $\mathrm{p}<0,05$ ).

Отже, істотні позитивні зміни після використання КТП в ЕГ дають можливість характеризувати таких осіб, як реалістичних у своїх судженнях, вчинках, критичних у ставленні до оточуючих, наполегливих, упертих, цілеспрямованих.

П’ятий показник вказує на покірність, підпорядкованість. У студентів КГ цей показник має певні особливості, які полягають у тому, що у процесі навчання у студентів 3 курсу у порівнянні з даними 1 - 2 курсів визначено істотні позитивні зрушення з 8,7 б. до 7,1 б (при $\mathrm{p}<0,05)$, які у подальшому знижуються до 7,0 - 6,9 б., що свідчить про позитивний вплив освітньо-професійної підготовки студентів.

У ЕГ студентів під впливом тренінгової програми показник покірності показник покірності істотно знижується 3 8,7 до 6,4 і до 5,0 балів. Отже, порівняльний аналіз покірності свідчить про позитивні зрушення у КГ з 3 курсу навчання, а в ЕГ після першого ж застосування КТП з першого до п'ятого курсу включно, що свідчить про їі ефективність.

Наступний показник визначає рівень залежності у взаємодії. У осіб контрольної групи цей показник суттєво не змінюється 3 першого по третій роки навчання включно $(8,1$ б. $-7,8$ б. $)$. 
Починаючи з четвертого року навчання у студентів КГ відмічається тенденція до зниження залежності у міжособистісній взаємодії, на 5 курсі вона суттєво знижується у порівнянні з початковими даними з 8,7 до 6,3 балів, що свідчить про позитивний вплив навчально-виховного процесу на становлення особистості у професійній діяльності ресторанного бізнесу.

В ЕГ студентів показник залежності істотно змінюється 3 7,9 до 6,5 балів після перших тренінгових заходів і в подальшому позитивно змінюється, як у порівнянні з початковими даними, так і у співставленні з даними КГ (з 6,5 до 5,0 балів, при р<0,05).

Отже, про ефективність використання КТП свідчать істотне позитивне зниження показника залежності у міжособистісній взаємодії, як у порівнянні з контрольною, так і у порівнянні з початковим результатом ЕГ.

Сьомий показник, який вказує на рівень співробітництва у осіб КГ набуває істотних позитивних змін на п'ятому році навчання (з 9,4 до 8,0 балів, при $р<0,05)$, що вказує на необхідність психокорекційної роботи зі студентами.

В ЕГ показник співробітництва після використання КТП позитивно змінювався в динаміці з 9,4 до 8,1 і 6,9 балів при р<0,05.

Отже, порівняльний аналіз показників КГ і ЕГ студентів показав ефективність КТП, про що свідчить входження студентів ЕГ в межі оптимального рівня адаптивної поведін- ки. Таких студентів можна охарактеризувати, як схильних до гнучкості, конформізму, вони ініціативні, досягають компромісу у конфліктній взаємодії.

Восьмий показник, спрямований на визначення альтруїстичності у взаєминах, у

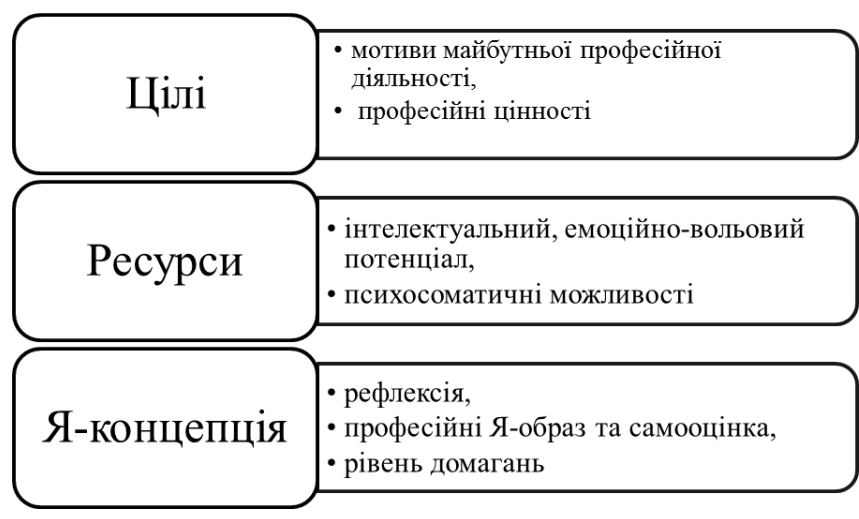

Рис 1. Особливості прояву типів монетарних уявлень студентів України та Європейського Союзу

КГ студентів починає суттєво змінюватися: у студентів 3 року навчання з 9,1 б. до 8,1 б. (при $\mathrm{p}<0,05)$ і у подальшому до п'ятого року навчання з 8,1 б. до 7,6 балів (при $p<0,05$ ). Це свідчить про те, що у процесі навчання і діяльності, починаючи з 4 курсу, у студентів формуються певні професійно-важливі якості i, водночас, це показує необхідність психологічного супроводу професійної підготовки студентів. Показники КГ перших два роки навчання вказують на те, що у студентів КГ спостерігається гіпервідповідальність, прагнення усім співчувати, надмірно активно допомагати.

У осіб ЕГ, починаючи 3 першого об- 
Динаміка цільового компоненту професійного становлення студентів

\begin{tabular}{|l|c|c|c|c|c|c|}
\hline \multirow{2}{*}{$\begin{array}{l}\text { Показники } \\
\text { Салах) }\end{array}$} & & & & & & \\
\cline { 2 - 7 } & 1 курс & 2 курс & 3 курс & 4 курс & 5 курс & 6 курс \\
\hline Психологія & & & & & & \\
\hline Правознавство & 24,30 & 22,40 & 22,97 & 21,03 & 23,20 & 25,08 \\
\hline Педагогіка & 24,58 & 22,54 & 19,35 & 20,85 & 20,4 & 21,71 \\
\hline
\end{tabular}

стеження, після використання КТП показники знизилися з 9,1 б. до 8,0 б. і у подальшому таке зниження відбувається з 8,0 б. до 6,0 б. на 5 році навчання (при $\mathrm{p}<0,05)$.

Отже, після використання КТП суттєво поліпшилися показники альтруїстичності у взаємодії як у порівнянні з КГ, так і в динаміці наступного освітньо-професійного навчання включно до 5 курсу.

Осіб ЕГ зразу ж після використання КТП і до кінця обстеження характеризують, як достатньо альтруїстичних, упевнених у собі, наполегливих, таких, що мають здібності керівника, наставника, організатора.

Таким чином, про поліпшення міжосо- бистісної взаємодії за результатами методики Т. Лірі свідчить той факт, що усі 8 показників зазнали позитивних змін після психокорекційної роботи, як у порівнянні в динаміці з початковим результатом ЕГ, так і з КГ студентів.

Водночас, серед стилів взаємодії, що характеризують неконформні тенденції - авторитарний, егоїстичний, агресивний, недовірливий, найбільш виражених позитивних змін у порівнянні з початковими результатами зазнали егоїстичний, агресивний і недовірливий ( до 6,1 - 5,9 б., при р<0,05).

Інша частина стилів (5 - 8) спрямовані на виявлення переважно конформних настанов, схильних до співпраці, конструктивного

Таблиия 2

Динаміка ресурсного компоненту професійного становлення студентів

\begin{tabular}{|l|c|c|c|c|c|c|}
\hline & $\begin{array}{r}\text { Показники } \\
\text { (у балах) }\end{array}$ & & & & & \\
\cline { 3 - 7 } Спеціальність & & & & & & \\
\hline Психологія & & & & & & \\
\hline Правознавство & 21,14 & 20,23 & 22,19 & 22,00 & 21,20 & 23,46 \\
\hline Педагогіка & 21,95 & 21,92 & 20,28 & 22,65 & 21 & 23,71 \\
\hline
\end{tabular}


розв'язання конфліктів і у цьому напрямі КТП сприяла схильності до співробітництва, гнучкості, досягнення компромісу у конкретних ситуаціях, комунікабельності, досягнення поставленої мети.

Істотні позитивні зміни після використання КТП у ЕГ студентів у порівнянні з початковими і контрольними результатами свідчить про поліпшення міжособистісної взаємодії, що спостерігається за показниками авторитарного, егоїстичного, агресивного, недові- діяльності. Ефективність впливу тренінгової програми на студентів ЕГ представлено за показниками методики К. Томаса (табл. 3.4.2).

У контрольній групі студентів спостерігається така стратегія взаємодії як конкуренція, показники якої суттєво зросли у порівнянні $з$ початковими даними (4,2 б. в період 4 року навчання до 5,4 б. і в подальшому до 5,9 б. при $p<0,05)$. Особливості показників експериментальної групи полягають у тому, що вони збільшуються після використання КТП з

Таблиия 3

Динаміка Я-концепції як компоненту професійного становлення студентів

\begin{tabular}{|l|l|l|l|l|l|l|}
\hline \multirow{2}{*}{$\begin{array}{r}\text { Показники } \\
\text { Спеціальність }\end{array}$} & & & & & & \\
\cline { 4 - 8 } & & & & & & \\
\hline Психологія & 22,02 & 20,30 & 20,83 & 22,17 & 23,33 & 24,54 \\
\hline Правознавство & 24,89 & 22,96 & 20,70 & 23,75 & 20,6 & 22,48 \\
\hline Педагогіка & 21,39 & 23,57 & 20,63 & 19,93 & 22,31 & 24,39 \\
\hline
\end{tabular}

рливого, залежного, співпрацюючого і альтруїстичного стилів взаємодії за методикою T. Лipi.

Наступна методика К. Томаса (в адаптованому варіанті В. Грішиної) спрямована на визначення способів реагування особистості на конфліктну ситуацію та дослідження стратегій взаємодії з іншими людьми: наскільки особистість схильна до суперництва чи співробітництва, прагне до компромісів, уникнення конфліктів чи, навпаки, намагається загострити їх, а також ступінь адаптації до сумісної
4,2 б. до 5,3 б (при р<0,05) і в подальшому не зазнають істотних змін, знаходячись на рівні 5,3 - 5,9 балів. Порівняння показників ЕГ і КГ студентів показує, що такі ж суттєві зміни спостерігаються до другого курсу включно (при $\mathrm{p}<0,05)$. Водночас, починаючи 3 третього року навчання стиль конкуренції спостерігається на рівні - 5,0 - 5,8 балів в КГ та в ЕГ 5,3 - 5,9 балів, суттєвих відмінностей при цьому не визначено.

Отже, ефективність КТП поягає у тому, що стиль конкурентності майбутніх фахів- 
ців в ЕГ досяг середнього рівня зразу ж у другому обстеженні і був стабільним до кінця навчання та кількість студентів у експериментальній групі з таким стилем взаємодії (зростає з 10\% до $15 \%)$.

Другий показник методики К. Томаса спрямований на з'ясування рівня співробітництва, яке включає налаштованість усіх учас- того 3'ясовано, що в динаміці спостереження у ЕГ студентів показник співробітництва на 1,4 - 3,0 балів вищий, ніж у КГ студентів (при $\mathrm{p}<0,05)$. Отже, порівняльний аналіз КГ і ЕГ показав стратегію взаємодії за показником співробітництво - це свідчить про ефективність використання КТП, що підтверджується достовірними відмінностями показників в ди-

Таблиия 4

\section{Динаміка загального рівня професійного становлення студентів}

\begin{tabular}{|l|c|c|c|c|c|c|}
\hline & \multicolumn{1}{|l|}{$\begin{array}{l}\text { Показники } \\
\text { (у балах) }\end{array}$} & & & & & \\
\cline { 3 - 7 } Спеціальність & 1 курс & 2 курс & 3 курс & 4 курс & 5 курс & 6 курс \\
\hline Психологія & & & & & & \\
\hline Правознавство & 67,42 & 63,05 & 66,25 & 64,97 & 67,20 & 73,08 \\
\hline Педагогіка & 71,37 & 67,04 & 60,33 & 67,1 & 66,25 & 67,9 \\
\hline
\end{tabular}

ників на взаємодію, на результат, що задовольняє інтереси сторін. Показники КГ студентів перших трьох років навчання мають стабільні показники без істотних відмінностей на рівні 5,4 б. - 6,2 б. Починаючи тільки з 4 року навчання у КГ студентів формується стратегія взаємодії щодо співробітництва (з 5,4 б. до 6,6 $-6,9$ б. при $\mathrm{p}<0,05)$.

Інше значення показника спостерігається в ЕГ. Так, після використання КТП показник співробітництва зростає з 5,4 б. до 6,8 б. і в подальшому зафіксовано ріст до 7,1 - 9,9 у випускників (при $\mathrm{p}<0,05)$. Тобто, 3 нижнього рівня середніх показників за цією шкалою (5 9 б.) зростання відбулося у ЕГ до високого рівня показників - 9,9 б. (при $p<0,05)$. Окрім наміці спостереження та тим, що кількість студентів, яка прагне до співробітництва зросла в ЕГ з 15\% до $35 \%$.

Незважаючи на, що стиль співробітництва 3 психологічної точки зору є найбільш оптимальним він одночасно самий складний для стратегічної та тактичної реалізації в техніці взаємодії сторін, він вимагає і часу, і відповідної психологічної підготовки, яку отримують студенти ЕГ в різні періоди освітньопрофесійного навчання при апробації цілеспрямованої тренінгової програми.

Саме співробітництво виявилося найбільш мудрим підходом до розв'язання завдання, задоволення інтересів і потреб кожної сторони, з наданням різних прав і можливос- 
тей один одному. Студенти ЕГ, які обрали даний стиль взаємодії як домінуючу стратегію в житті і бізнесі досягають найкращих успіхів у взаємодії з людьми при цьому не страждають їх особистісні уподобання і справи.

Третя стратегія взаємодії 3 іншими людьми має свої суттєві особливості, адже компроміс передбачає взаємні поступки, коли частково задовольняється своє бажання i приймається до виконання бажання іншої сторони. Взаємодія партнерів іноді нагадує стиль співробітництва, але компроміс здійснюється на поверхневому рівні, коли покроково розробляється компромісне рішення, яке б задовільнило б обидві сторони.

Потрібно зазначити, що у КГ студентів така стратегія приймається 35\% обстежуваних. В динаміці спостерігається певна стабільність показника компромісу до 4 курсу навчання 5,6 б. - 5,9 б., які на завершальному етапі навчання збільшуються до 6,1 - 6,4 б. (при $\mathrm{p}<0,05)$.

Під впливом КТП у ЕГ студентів показник компромісу підвищується з 5,6 до 6,7 балів (при $р<0,05)$ і починаючи 33 по 5 рік навчання він залишається на рівні 7,1 - 7,5 балів (при $\mathrm{p}<0,05$ ).

Отже, стратегія компромісу у взаємодії після застосування КТП у ЕГ знижується 3 $35 \%$ до $22 \%$ обстежуваних, водночас, суттєві відмінності цього показника від фонових і початкових результатів свідчить про позитивний вплив КТП на формування певних домінант- них стратегій взаємодії.

Для четвертої стратегії - уникнення притаманне прагнення до самоусунення від ситуації, відсутність бажання до кооперації й досягнення своїх цілей. Тобто особа свідомо відмовляється від розв'язання проблеми, не відстоює свої права, відмовляється від взаємодії $з$ іншими людьми.

Нами з'ясовано, що для 28\% студентів уникнення - це одна із важливих стратегій взаємодії. У КГ студентів стратегія уникнення спостерігається на середньому рівні 7,6 б. 7,2 б. до 4 курсу навчання включно і тільки на 5 році цей показник істотно знизився до 6,4 б. (при $\mathrm{p}<0,05$ ).

Експериментальній групі притаманні свої особливості, коли цей показник після перших тренінгів суттєво знизився з 7,6 до 6,6 б. і в подальшому до 6,4-6,1 б.

Про ефективність використання КТП свідчить те, що показник уникнення суттєво нижчий, ніж у КГ 7,6 б. - 6,6 - 6,1 б., при $\mathrm{p}<0,05$ включно до 4 року навчання, а в динаміці обстежених у самій ЕГ цей показник суттєво підвищився після першого тренінгового впливу і зберігався до кінця навчання на рівні $6,2-6,0$ балів (при $p<0,05)$.

Стиль пристосування, як домінуюча стратегія взаємодії людини з іншими, протилежний суперництву і передбачає пониження своїх інтересів заради інтересів іншого. При цьому можуть бути різні варіанти пристосування. Сприятливий варіант, коли особа йде 
на поступки свідомо, добровільно і не жалкує та відчуває себе комфортно. Інший випадок, коли людина не готова до пристосування, а об'єктивні чи суб'єктивні обставини змушують йти на пристосування, що викликає когнітивний дисонанс і суб'єктивні почуття тиску, маніпуляції, що можуть призвести до внутрішнього конфлікту. Тобто стратегія пристосування для оточуючих вигідна, але психологічного важка для особи, яка пристосовується до певних обставин.

У КГ $12 \%$ студентів обрали пристосування, як стратегію взаємодії з оточуючими. Цей показник визначено на рівні 6,7 б. - 6,0 б. у порівнянні з результатами ЕГ і він змінився після використання КТП з 6,6 б. до 5,6 б. та був достатньо стабільним протягом усього періоду дослідження (5,6 - 5,1 б).

Отже, КТП виявилася ефективною у ЕГ студентів, про це свідчать істотні відмінності між початковими і контрольними результатами, а також те, що кількість студентів, що обрали стратегію пристосування знизилась 3 12\% до 6\%.

Такими чином, аналіз результатів домінуючої стратегії взаємодії за методикою К. Томаса показав, що корекційно-тренінгова програма (КТП) виявилася ефективною, про що свідчать суттєві позитивні зміни в ЕГ у порівнянні з початковою і контрольною стратегією співробітництва, яку опанували студенти (з 15\% до 35\%), зниження стратегії компромісу з $35 \%$ до $22 \%$, уникнення з $28 \%$ до
16\% та пристосування 3 12\% до 6\%, також збільшилася конкуренція з 10\% до 15\%.

3 метою визначення рівні комунікативних і організаторських здібностей та ефективності впливу КТП використовувалася методика КОЗ (табл. 3.4.3)

У КГ з'ясовано, що рівень організаторських здібностей змінився 3 0,52 ум.од. до 0,66 - 0,69 і він знаходиться в межах нижче середнього (2 бали) за інтерпретацією результатів методики.

В ЕГ студентів після застосування КТП організаторські здібності поліпшилися до 0,67 (3 бали) і з 4 курсу навчання цей показник дорівнює 0,71 - 089, тобто він досяг високого рівня (5 балів) за інтерпретаційною оцінкою.

Комунікативні здібності у осіб контрольної групи до 4 курсу зафіксовано на рівні нижче середнього (2 бали) і тільки на останньому році навчання цей показник досяг середнього рівня 0,57 - 0,59 (3 бали), що свідчить про необхідність застосування тренінгової програми та формування цих професійноважливих якостей у майбутніх фахівців РБ.

У студентів ЕГ комунікативні здібності помітно зросли ж після перших тренінгів 3 0,46 до 0,62 (при $\mathrm{p}<0,05)$ у подальшому цей показник поліпшується до $0,78-0,89$ (5 балів), що відповідає високому рівню комунікативних здібностей і свідчить про ефективність використання тренінгової програми.

Такими чином, порівняльний аналіз 
контрольної і експериментальної груп показав, що використання КТП виявилося ефективним щодо розвитку комунікативних і організаторських здібносте й, показники яких суттєво поліпшилися зразу ж після їі використання і в подальшому підтримувалися і формувалися іншими тренінгами, що сприяло високому рівню їх оцінок до 4 - 5 балів за інтерпретаційною шкалою.

Так особам експериментальної групи 3 оцінкою в 3 бали притаманний середній рівень комунікативних і організаторських здібностей. Вони прагнуть до контактів з людьми, не обмежують коло своїх занять, наполягають на власній думці, планують свою роботу. Ця група потребує подальшої цілеспрямованої роботи. В ЕГ позитивний результат з оцінкою комунікативних і організаторських здібностей до 5 балів отримали студенти після 4 і 5 курсів після проходження тренінгу особистісного зростання і мотивації до підприємницької діяльності на 4 курсі та на п'ятому тренінгу лідерського потенціалу.

Студентам ЕГ на завершальному етапі освітньо-професійної діяльності притаманний високий рівень прояву комунікативних і організаторських здібностей. Вони не губляться в новій обстановці, знаходять друзів, постійно прагнуть розвивати коло своїх знайомих, здатні приймати рішення в критичних ситуаціях. Комунікативні і організаторські здібності $\epsilon$ важливим компонентом і передумовою високого рівня професіоналізму для майбутніх фа- хівців РБ.

Висновок. Ефективність використання КТП здійснювали за результатам порівняльного аналізу показників КГ і ЕГ студентів 15 років навчання.

Комплекс інформативних методик включав: показники методів дослідження комунікативної сфери особистості «Діагностики міжособистісних відносин» (Т. Лірі), «Виявлення стратегій поведінки в конфлікті» (К. Томаса), «Дослідження комунікативних i організаторських здібностей» (В. Бодров), що визначені за факторним аналізом як фактор 1 (F-1), щодо його значення у структурі важливості для формування професійних якостей майбутніх фахівців ресторанного бізнесу.

Доведено ефективність використання КТП її позитивного впливу на комунікативну сферу обстежуваних завдяки цілеспрямованим тренінговим циклам. Вони здійснювалися під час формуючого експерименту перед повторним обстеженням (тренінг спілкування і адаптаційного входження студентів в освітньопрофесійну діяльність), а також на другому курсі - тренінг безконфліктної взаємодії. В подальшому навчанні використовувалися тренінги, які підтримували досягнуті результати.

3'ясовано, що після використання КТП у студентів ЕГ у порівнянні з початковими i контрольними результатами поліпшилися показники за усіма 8 октантами - 1) авторитарності; 2) егоїстичності; 3) агресивності; 4) не- 
довірливості; 5) покірності; 6) залежності; 7) співробітництва; 8) альтруїстичності.

Визначено, що показники психограми міжособистісної взаємодії з 1 по 4 характеризують неконформні тенденції і схильність до конфліктних проявів (особливо 3 і 4).

Встановлено, що в ЕГ після використання КТП студентам притаманні більш незалежні позиції, наполегливість у досягненні мети, відстоюванні своєї точки зору, схильність до конкуренції. За наступними 4 октантами - 58 в ЕГ студентам притаманні такі особливості, як: спрямованість на розв'язання конфліктних ситуацій, самостійність у прийнятті рішень, менший вплив оточення на думку і дії, схильність до компромісів, прийняття реальних обставин.

Позитивний вплив КТП в ЕГ студентів підтверджується результатами методики К. Томаса.

Доведено, що домінуючими стратегіями взаємодії після використання КТП у студентів ЕГ стали співробітництво (збільшилося 3 $15 \%$ до $35 \%$ ), компроміс (зменшився з $35 \%$ до $22 \%$ ), уникнення (зменшилося з 28\% до 16\%), конкуренція (збільшився з 10\% до 15\%) і пристосування (зменшилося з 12\% до 6\%).

За результатами порівняльного аналізу комунікативних і організаторських здібностей у ЕГ встановлено істотно вищі показники після застосування КТП, які змінились (з початкових результатів на рівні 2 балів, що за інтерпретаційною оцінкою вважається нижче сере- днього) до 4 і навіть 5 балів, що розцінюється як високий і дуже високий рівень проявів комунікативних та організаторських здібностей.

\section{Перелік використаних джерел:}

1. Карамушка Л. М. Технологія психологічної підготовки персоналу організацій до роботи в умовах соціальноекономічних змін (на матеріалі освітніх організацій) /Л. М. Карамушка, О.А.Філь, Г.Л.Федосова та ін.. - К. : Науковий світ, 2008. -230 с.

2. Кокун О. М. Психологія професійного становлення сучасного фахівця / О.М. Кокун: Монографія. - К.: ДП "Інформ.-аналіт. агенство", 2012. - 200 с.

3. Корольчук M. С., В.М. Крайнюк Теорія і практика професійного психологічного відбору: Навчальний посібник для студентів вищих навчальних закладів. - К.: Ніка-Центр, 2012 - 536 с.

4. Максименко С. Д., Мазаракі А.А. Підприємництво, психологічні, організаційні та економічні аспекти / Навчальний посібник для студентів вищих навчальних закладів / С.Д. Максименко, А.А. Мазаракі, - К.: Київ. нац. торг.-екон. ун., $2012-720$ с.

5. Сучасні концепції, передумови та перспективи розвитку підприємств України / М. Г. Бойко/ під заг. ред. К.Ф. Ковальчука.- IMA-прес, 2012.- с. 29-42.

\section{References (Transliteration):}

1. Karamushka L. M. TehnologIya psihologIchnoYi pIdgotovki personalu organIzatsIy do roboti $\mathrm{v}$ umovah sotsIalno-ekonomIchnih zmIn (na materIalI osvItnIh organIzatsIy)/L. M. Karamushka, O.A.FIl, G.L.Fedosova ta In.. - K. : Naukoviy svIt, 2008. -230 s.

2. Kokun O. M. Psihologlya profesIynogo stanovlennya suchasnogo fahIvtsya / O.M. Kokun: Monograflya. - K.: DP "Inform.-analIt. agenstvo", 2012. - 200 s.

3. Korolchuk M. S., V.M. Kraynyuk Teorlya I praktika profeslynogo psihologIchnogo vIdboru: Navchalniy 
posIbnik dlya studentIv vischih navchalnih zakladIv. - K.: NIka-Tsentr, 2012 - $536 \mathrm{~s}$.

4. Maksimenko S. D., MazarakI A.A. PIdpriEmnitstvo, psihologIchnI, organIzatsIynI ta ekonomIchnI aspekti / Navchalniy posIbnik dlya studentIv vischih navchalnih zakladIv / S.D. Maksimenko, A.A. MazarakI, - K.: KiYiv. nats. torg.-ekon. un., $2012-720 \mathrm{~s}$.

5. Suchasni kontseptsiyi, peredumovi ta perspektivi rozvitku pIdpriEmstv Ukrayini / M. G. Boyko/ pId zag. red. K.F. Kovalchuka.- IMA-pres, 2012.- s. 29-42.

\section{Pryymuk Olesia}

PhD student of Kyiv National University of Trade and Economics, Kyiv (Ukraine)

\section{EFFICIENCY OF THE INFLUENCE OF THE INTEGRATED TRAINING PROGRAM ON DEVELOPMENT OF THE COMMUNICATIVE COMPONENT OF FUTURE RESTAURANT BUSINESS SPECIALISTS}

\section{ABSTRACT}

After analyzing the entire range of requirements for communication between subject and object in the restaurant industry, the main object of study appeared determination of the effectiveness of remedial training program (CRL) for the development of communicative component POF future specialists of Belarus.

The purpose and main objectives of the study were found positive effect remedial training program (KTP) in communicative component of students in their educational and professional activity, indicating high rates of style and structure of interpersonal interaction, formation of appropriate ways to respond to conflict of personality the situation with the advantage of the dominant strategy of interaction with others cooperation, compromise, avoidance, competition and accessories, as well as identifying indicators significantly higher the structure organizational and communication skills of future professionals of the restaurant business.

It was established that improved communication properties of future professionals of the restaurant business after using DHC promotes stronger interaction - its activity, rapid orientation in difficult situations, initiative, making independent decisions, defending their own opinion, persuasion of others, the ability to organize various events.

Determined that the development of communication and organizational skills are a necessary prerequisite tasks and efficiency of future specialists professional restaurant business related to professional communication and organization collective process.

Key words: communicative component, efficiency, complex-training program, professionally important quality.

\section{Приймук Олеся Александровна}

Аспирант кафедры психологии Киевского нациионального торгово-экономического университета, г. Киев (Украина)

ЭФФЕКТИВНОСТЬ ВЛИЯНИЯ
КОМПЛЕКСНО-ТРЕНИНГОВОЙ
ПРОГРАМЫ НА РАЗВИТИЕ
КОММУНИКАТИВНОГО
КОМПОНЕНТУ БУДУЩИХ
СПЕЦИАЛИСТОВ РЕСТОРАННОГО
БИЗНЕСА

Аннотация. Проанализировав весь 
спектр требований в отношении субъекта и объекта коммуникации в сфере ресторанной индустрии, основной задачей исследования оказалось определение эффективности влияния коррекционно-тренинговой программы (КТП) на развитие коммуникативного компонента ПИЯ будущих специалистов РБ.

Соответствии с целью и основной задачи исследования было выяснено положительное влияние коррекционно тренинговой программы (КТП) на коммуникативную составляющую студентов в процессе их образовательнопрофессиональной деятельности, о, свидетельствующие высокие показатели стиля и структуры межличностного взаимодействия, сформированность адекватных способов реагирования личности на конфликтную ситуацию с преобладанием в доминирующих стратегиях взаимодействия с другими людьми - сотрудничества, компромисса, избегания, конкуренции и приспособления, а также определение существенно более высоких показателей в структуре организационных и коммуникативных способностей будущих специалистов ресторанного бизнеса.

Установлено, что улучшение коммуникативных свойств будущих специалистов ресторанного бизнеса после использования КТП способствует более прочной взаимодействия - ее активности, быстрой ориентации в сложных ситуациях, инициативности, принятии самостоятельных решений, отстаивание собственного мнения, убеждения других, уме- ние организовывать различные мероприятия.

Определено, что развитие коммуникативных и организаторских способностей необходимо задачей и условием эффективности профессиональной деятельности будущих специалистов ресторанного бизнеса, связанные с профессиональным общением и организацией коллективного процесса.

Ключевые слова: коммуникативный компонент, эффективность, комплекснотренинговая программа, профессионально важный качества.
Дата отримання статті: 01.04.2017 Дата рекомендації до друку: 05.04.2017 